Article

\title{
A Facile and Efficient Procedure for the Synthesis of New Benzimidazole-2-thione Derivatives
}

\author{
Augusto Rivera *, Mauricio Maldonado and Jaime Ríos-Motta \\ Departamento de Química, Facultad de Ciencias, Universidad Nacional de Colombia, Sede Bogotá, \\ Cra.30 No.45-03, Bogotá 111321, Colombia; E-Mails: mmaldonadov@unal.edu.co (M.M.); \\ jariosmo@unal.edu.co (J.R.-M.) \\ * Author to whom correspondence should be addressed; E-Mail: ariverau@unal.edu.co; \\ Tel.: +57-1-316-5000; Fax: +57-1-316-5220.
}

Received: 4 May 2012; in revised form: 27 June 2012 / Accepted: 9 July 2012 /

Published: 17 July 2012

\begin{abstract}
A series of benzimidazole-2-thione derivatives was synthesized using a reaction between the macrocyclic aminal $16 H, 13 H-5: 12,7: 14$-dimethanedibenzo[ $[$,i] $][1,3,6,8]$ tetraazecine (DMDBTA, 5) and various nucleophiles in the presence of carbon disulfide. A full chemical characterization using IR, ${ }^{1} \mathrm{H}-,{ }^{13} \mathrm{C}-\mathrm{NMR}$ and GC-MS analyses of the new compounds is provided. These compounds were separated from the reaction mixture by column chromatography (CC) in highly pure form in $15 \%-51.4 \%$ yield.
\end{abstract}

Keywords: benzimidazole-2-thione; benzimidazole; sulfur chemistry; aminal cage

\section{Introduction}

The reaction between carbon disulfide and amines was originally reported by Hoffmann in the 19th century [1]. This reaction with primary and secondary aliphatic amines in ethanol yields reactive dithiocarbamate salt intermediates $\mathbf{1}$ that can be converted into S-alkyl dithiocarbamates $\mathbf{2}$, which have several biological activities, via reaction with electrophiles or into dithiocarbamic acids by treatment with mineral acids [2]. In the case of aliphatic diamines, the treatment of the dithiocarbamate intermediate with acid gives cyclic thioureas 3 [3]. In contrast, the reaction with $o$-phenylenediamine under basic conditions afforded 2-mercaptobenzimidazole (4) [4,5] (Figure 1). In recent years, cyclic thioureas and mercaptobenzimidazoles have had important industrial applications as anticorrosive agents [6-8], friction attenuators [9] and heavy metal adsorbents [10]. Moreover, derivatives of cyclic 
thioureas have important roles in medicinal chemistry owing to their utility as antiseptic [11], antidepressive [12], antitumour [13], and antibacterial agents [14-16]. In addition, thioureas have been used as ligands in copper (I)-based complexes [17,18] and in complexes with other metals [19].

Figure 1. The chemical structures of compounds 1-6.<smiles>[R]N([R])C(=S)[S-]</smiles>

1<smiles>[R]SC(=S)N([R])[R]</smiles>

2<smiles>S=C1NCCN1</smiles>

3<smiles>Sc1nc2ccccc2[nH]1</smiles>

4<smiles>c1ccc2c(c1)CN1C[C@H]3CN2N(C3)c2ccccc21</smiles>

5<smiles>S=C1SCN2CN3CN(C[C@@H]13)c1ccccc12</smiles>

6

In continuation of our work with the benzoaminal $6 H, 13 H-5: 12,7: 14$-dimethanedibenzo [d,i]-[1,3,6,8]tetraazecine (DMDBTA, 5) [20-24], we recently became interested in synthesizing the cyclic dithiocarbamate $8 H, 15 H-5: 14,9: 16$-dimethanedibenzo[d,i]-[1,3,6,8,11]thiatetraazatricycledodecine-6-thione (6). To obtain this product, we planned to use DMDBTA (5) and carbon disulfide in ethanol, following the method reported by Donia et al. [25]. In earlier attempts, we found that the reaction of 5 with carbon disulfide in ethanol did not provide the desired cyclic dithiocarbamate 6. Instead, we found that 5 reacts with carbon disulfide to produce 1,3-bis(ethoxymethyl)-1,3-dihydro$2 H$-benzimidazole-2-thione (7b) and 1-(ethoxymethyl)-1H-benzimidazole (8b) (Scheme 1).

Scheme 1. General reaction of 5 with nucleophiles in the presence of $\mathrm{CS}_{2}$

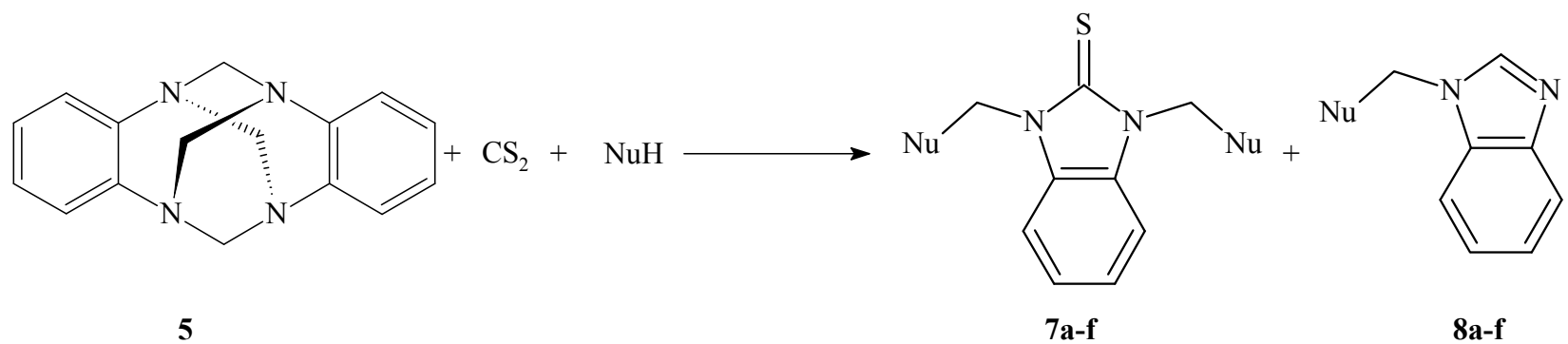

$\mathrm{NuH}=$ a) $\mathrm{MeOH}$, b) $\mathrm{EtOH}$, c) $n-\mathrm{PrOH}$, d) $n-\mathrm{BuOH}$, e) $\mathrm{HCN}$, f) $\mathrm{BtH}$

The effects of the solvent on the product yields were examined using $\mathbf{5}$ as a substrate in various alcohols, including methanol, ethanol, $n$-propanol, $n$-butanol and $t$-butanol. Contrary to our expectations, when 5 was treated with $t$-butanol, the desired derivatives were not obtained. The efficacy of using 
other nucleophiles was demonstrated by reacting 5 with $\mathrm{CS}_{2}$ and either hydrogen cyanide or benzotriazole in the aprotic polar non-nucleophilic solvents 1,4-dioxane and acetonitrile, respectively.

\section{Results and Discussion}

We found the optimum conditions for the synthesis of compounds $7 \mathbf{a}-\mathbf{f}$ and $\mathbf{8 a}-\mathbf{f}$. These products were obtained in good yields with high purities. Both the analytical and spectral data (IR, ${ }^{1} \mathrm{H}-\mathrm{NMR}$, ${ }^{13} \mathrm{C}-\mathrm{NMR}$ and GC-MS analyses) of all synthesised 1,3-bis(alcoxymethyl)-1,3-dihydro- $2 \mathrm{H}$ benzimidazole-2-thiones 7a-f and 1-(alkoxymethyl)-1,3-dihydro-2H-benzimidazole compounds 8a-f were in full agreement with the proposed structures.

The IR data for benzimidazole-2-thiones 7a-d clearly indicate the presence of the $\mathrm{C}=\mathrm{S}$ group, with $v(\mathrm{C}=\mathrm{S})$ vibrations at 1098, 1099, 1104 and 1108. In the $1 \mathrm{H}-\mathrm{NMR}$ spectra, the $\mathrm{N}-\mathrm{CH}_{2}-\mathrm{O}$ protons of the hemiaminal moiety of 1,3-bis(alcoxymethyl)-1,3-dihydro- $2 H$-benzimidazole-2-thione appeared as a singlet at approximately 5.79-5.82 ppm. In the ${ }^{13} \mathrm{C}-\mathrm{NMR}$ spectra, the signal of the thiourea functional group was clearly observed at $171.8-169.3 \mathrm{ppm}$, and these signals are consistent with the signals of analogous molecules [26]. The attributions of the other signals in ${ }^{13} \mathrm{C}-\mathrm{NMR}$ spectra were based on the analysis of the HMQC and HMBC spectra. The molecular ions and fragment ions in the mass spectra were also consistent with the assigned structures. The reaction with other nucleophiles in the presence of an inert solvent under the same conditions produces benzimidazole and benzimidazole-2-thione derivatives. When the reaction was carried out with the cyanide anion, 1,3-bis(cyano-1-ylmethyl)-1,3dihydro-2 $H$-benzimidazole-2-thione (7e) and $1 H$-benzimidazol-1-yl-acetonitrile (8e) were obtained; in an analogous manner, the reaction with benzotriazole $(\mathrm{BtH})$ afforded 1,3-bis(1H-1,2,3-benzotriazol1-ylmethyl)-1,3-dihydro-2 $H$-benzimidazole-2-thione (7f) and 1-(1H-benzimidazol-1-ylmethyl)- $1 H$ 1,2,3-benzotriazole $(\mathbf{8 f})$. The structures of these heterocyclic systems were confirmed by the spectroscopic data.

As shown in Table 1, the results reveal that the yield of the reaction depends on the size of the nucleophile. Consequently, the use of $t$-butanol under the same reaction conditions afforded complex mixtures, from which we were unable to isolate the expected benzimidazole-2-thione and 1-H-benzimidazole derivatives.

Table 1. Yields of benzimidazole-2-thione (7a-f) and 1- $H$-benzimidazole $(\mathbf{8 a}-\mathbf{f})$ derivatives.

\begin{tabular}{ccccc}
\hline Entry & NuH & $\mathbf{7 ( \% )}$ & $\mathbf{8}(\mathbf{\%})$ & t (h) \\
\hline $\mathbf{a}$ & $\mathrm{MeOH}$ & 48.5 & 51.4 & 24 \\
$\mathbf{b}$ & $\mathrm{EtOH}$ & 30.1 & 32.3 & 30 \\
$\mathbf{c}$ & $n-\mathrm{PrOH}$ & 23.3 & 24.5 & 34 \\
$\mathbf{d}$ & $n-\mathrm{BuOH}$ & 15.0 & 16.7 & 40 \\
$\mathbf{e}$ & $\mathrm{HCN}$ & 25.3 & 26.0 & 24 \\
$\mathbf{f}$ & $\mathrm{BtH}$ & 35.2 & 36.7 & 24 \\
\hline
\end{tabular}

According to these results, in the presence of an adequate nucleophile, the reactions efficiently proceed to provide the ring opening of the benzoaminal. Thus, the first step of the reaction between $\mathbf{5}$ and $\mathrm{CS}_{2}$ might be fast, and the second step, involving the nucleophilic attack of the dithiocarbamate salt, is slower and consequently should be the rate-limiting step. The onset of the reaction is indicated 
by the evolution of hydrogen sulphide, whose odour was noticeable during the reaction. Based on these results, we propose a possible pathway for the formation of the products (Scheme 2).

Scheme 2. Proposed pathway for the formation of $7 \mathbf{a}-\mathbf{f}$ and $\mathbf{8 a}-\mathbf{f}$.

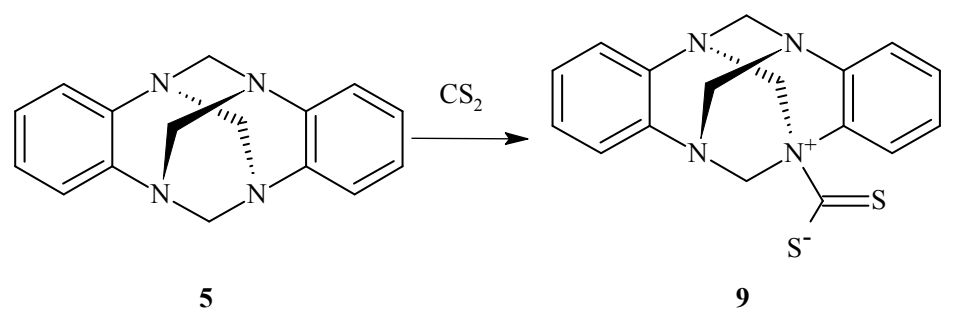<smiles>Cc1ccc(N(CN)CN)c(N2CN3CCN(CN)CN(C2)c2ccccc23)c1</smiles><smiles>CC[NH2+]CNc1ccccc1C[NH+]1CN(CC#N)c2ccccc21</smiles>

12

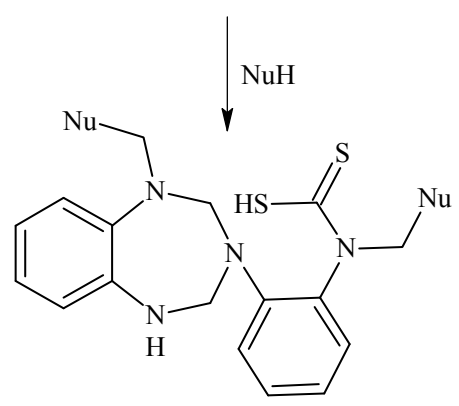

11

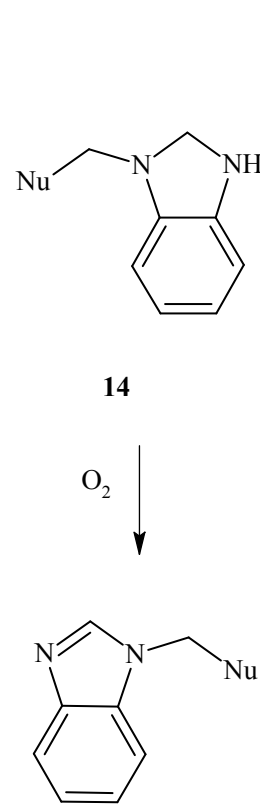

8a-f

$$
\mathrm{NuH}
$$

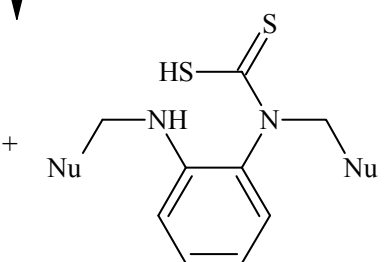

13

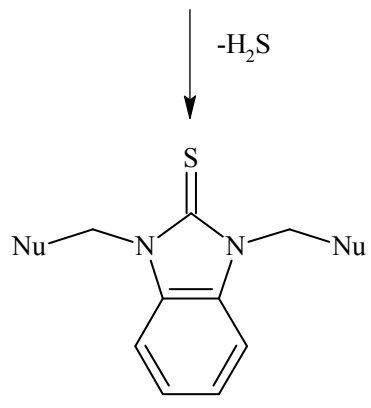

7a-f

We assumed that carbon disulfide first reacts with $\mathbf{5}$ to form the expected dithiocarbamate salt $\mathbf{9}$ as a very active intermediate. This intermediate then reacts with one equivalent of the nucleophile, a reaction that includes a proton shift, to produce a second intermediate $\mathbf{1 0}$ that is able to form $\mathrm{S}-\mathrm{H} \cdots \mathrm{N}$ intramolecular hydrogen bonds. This intramolecular interaction in this intermediate decreases the relative stability of the intermediate and induces the attack of a second equivalent of nucleophile to give a 1-substituted-3-aryl-2,3,4,5-tetrahydro-1H-1,3,5-benzotriazepine intermediate 11, in which a proton transfer induces an intramolecular rearrangement to give 12. The presence of a positive charge 
on the $1 \mathrm{H}$-benzimidazole ring of $\mathbf{1 2}$ makes this adduct fairly labile, and the central $\mathrm{NCH}_{2} \mathrm{~N}$ moiety in 12 undergoes a regioselective cleavage involving the preferential attack by a third equivalent of nucleophile to give $\mathbf{1 3}$ and $\mathbf{1 4}$. Then, the benzimidazole-2-thiones $\mathbf{7 a - f}$ are obtained by cyclisation of the acyclic intermediate $\mathbf{1 3}$ with the elimination of a molecule of $\mathrm{H}_{2} \mathrm{~S}$. Monosubstituted-benzimidazolines 14a-f, the other products formed from 12 under these reaction conditions, smoothly undergo oxidation in air to yield the 1-(alkoxymethyl)-1,3-dihydro- $2 H$-benzimidazole derivatives 8a-f, as observed previously for other benzimidazoline derivatives [27]. Alcohols and cyclic ethers are good solvents for this oxidative process [28-30].

\section{Experimental}

\subsection{General}

Melting points were determined on an Electrothermal 9100 melting point apparatus and are uncorrected. Chemicals were used without further purification. FT-IR spectra were recorded in potassium bromide pellets using Thermo Nicolet IS10 spectrophotometer. ${ }^{1} \mathrm{H}-\mathrm{NMR}$ and ${ }^{13} \mathrm{C}-\mathrm{NMR}$ spectra were recorded in $\mathrm{CDCl}_{3}$ using a Bruker Avance AV-400 MHz spectrometer operates at 400 $\mathrm{MHz}$ for ${ }^{1} \mathrm{H}$ and $100 \mathrm{MHz}$ for ${ }^{13} \mathrm{C}$. Elemental analyses $(\mathrm{C}, \mathrm{H}, \mathrm{N})$ were determined in a Thermo Scientific Flash 2000. Combined GC-MS analysis was performed on a Hewlett-Packard 5973 mass spectrometer at $70 \mathrm{eV}$ coupled to a Hewlett-Packard 6890 gas chromatograph.

General procedure for the reaction of DMDBTA with $\mathrm{CS}_{2}$ in alcohols: Following the general procedure described in the literature [25], carbon disulfide $(0.95 \mathrm{mmol}, 0.07 \mathrm{~mL})$ was added dropwise over $30 \mathrm{~min}$ to a shaking solution of DMDBTA $(0.95 \mathrm{mmol})$ in the desired alcohol $(30 \mathrm{~mL})$. This yellow solution was stirred at room temperature in the dark until the DMDBTA had dissolved completely. The reaction was monitored by TLC. The removal of the solvent at reduced pressure $(50 \mathrm{mmHg})$ resulted in the collection of a resinous solid that was then purified via column chromatography on silica gel (elution using benzene:ethyl acetate in a 9:1 mixture).

Procedure for the reaction of DMDBTA with benzotriazole and $C S_{2}$ : A mixture of DMDBTA (0.95 mmol, $0.25 \mathrm{~g}), 1 \mathrm{H}$-benzotriazole $(2.85 \mathrm{mmol}, 0.34 \mathrm{~g}$ ) and carbon disulfide $(0.95 \mathrm{mmol}, 0.07 \mathrm{~mL})$ was stirred in 1,4-dioxane $(30 \mathrm{~mL})$ for $24 \mathrm{~h}$. at room temperature in the dark yielding a resinous solid. The precipitated solid was collected and purified via column chromatography on silica gel (elution using benzene: ethyl acetate in a 9:1 mixture).

Procedure for the reaction of DMDBTA with cyanide anion and $C S_{2}$ : To a solution of DMDBTA $(0.95 \mathrm{mmol}, 0.25 \mathrm{~g})$ and carbon disulfide $(0.95 \mathrm{mmol}, 0.07 \mathrm{~mL})$ in acetonitrile $(15 \mathrm{~mL})$, an excess of hydrogen cyanide was bubbled in slowly. The reaction mixture was stirred at room temperature in the dark for $24 \mathrm{~h}$. The removal of the solvent at reduced pressure $(50 \mathrm{mmHg})$ resulted in the collection of a resinous product that was then purified via column chromatography on silica gel (elution using benzene:ethyl acetate in a 9:1 mixture). 


\subsection{Physical and Spectral Data}

1,3-Bis(methoxymethyl)-1,3-dihydro-2H-benzimidazole-2-thione (7a): White solid; m.p. 99-101 ${ }^{\circ} \mathrm{C}$; ${ }^{1} \mathrm{H}-\mathrm{NMR} \delta: 3.24\left(6 \mathrm{H}, \mathrm{s},-\mathrm{CH}_{3}\right), 5.79\left(4 \mathrm{H}, \mathrm{s}, \mathrm{N}-\mathrm{CH}_{2}-\mathrm{O}\right), 7.24(2 \mathrm{H}, \mathrm{m}), 7.35(2 \mathrm{H}, \mathrm{m}) ;{ }^{13} \mathrm{C}-\mathrm{NMR} \delta: 52.6$, 74.3, 111.5, 121.9, 132.5, 171.8; IR $v_{\max }\left(\mathrm{cm}^{-1}\right): 1,108(\mathrm{C}=\mathrm{S}), 1,285$ (C-O); EIMS, $70 \mathrm{eV}, \mathrm{m} / z: 238$ $\left(\mathrm{M}^{+}\right)$; Anal. Calcd. for $\mathrm{C}_{11} \mathrm{H}_{14} \mathrm{~N}_{2} \mathrm{O}_{2} \mathrm{~S}$ (238.36): C, 55.44; H, 5.92; N, 11.76; S, 13.46. Found: C, 55.23; H, 5.96; N, 11.46; S, 13.22.

1,3-Bis(ethoxymethyl)-1,3-dihydro-2H-benzimidazole-2-thione (7b): Melting point $103-104{ }^{\circ} \mathrm{C}$ (lit. [31] $\left.104-106^{\circ} \mathrm{C}\right)$.

1,3-Bis(propoxymethyl)-1,3-dihydro-2H-benzimidazole-2-thione (7c): White solid; m.p. 120-122 ${ }^{\circ} \mathrm{C}$; ${ }^{1} \mathrm{H}-\mathrm{NMR} \delta: 0.91\left(6 \mathrm{H}, \mathrm{t}, J=6.9 \mathrm{~Hz},-\mathrm{CH}_{3}\right), 1.59\left(4 \mathrm{H}, \mathrm{s}, J=6.9 \mathrm{~Hz}, \mathrm{O}-\mathrm{CH}_{2} \underline{\mathrm{CH}}_{2} \mathrm{CH}_{3}\right), 3.46(4 \mathrm{H}, \mathrm{q}$, $\left.J=6.9 \mathrm{~Hz}, \mathrm{O}-\underline{\mathrm{CH}}_{2} \mathrm{CH}_{2} \mathrm{CH}_{3}\right), 5.82\left(4 \mathrm{H}, \mathrm{s}, \mathrm{N}-\mathrm{CH}_{2}-\mathrm{O}\right), 7.27(2 \mathrm{H}, \mathrm{m}), 7.39(2 \mathrm{H}, \mathrm{m}) ;{ }^{13} \mathrm{C}-\mathrm{NMR} \delta: 10.7$, 22.5, 64.9, 73.7, 110.3, 123.8, 132.4, 169.3; IR $v_{\max }\left(\mathrm{cm}^{-1}\right): 1,098(\mathrm{C}=\mathrm{S}), 1,289$ (C-O); EIMS, $70 \mathrm{eV}$, m/z: $294\left(\mathrm{M}^{+}\right)$; Anal. Calcd. for $\mathrm{C}_{15} \mathrm{H}_{22} \mathrm{~N}_{2} \mathrm{O}_{2} \mathrm{~S}$ (294.40): C, 61.19; H, 7.53; N, 9.52; S, 10.89. Found: C, 61.05; H, 7.66; N, 9.48; S, 10.85 .

1,3-Bis(butoxymethyl)-1,3-dihydro-2H-benzimidazole-2-thione (7d): White solid; m.p. 124-126 ${ }^{\circ} \mathrm{C}$; ${ }^{1} \mathrm{H}-\mathrm{NMR} \delta: 0.84\left(6 \mathrm{H}, \mathrm{t}, J=6.7 \mathrm{~Hz},-\mathrm{CH}_{3}\right), 1.65-1.68\left(8 \mathrm{H}, \mathrm{m}, \mathrm{O}-\mathrm{CH}_{2} \underline{\mathrm{CH}}_{2} \mathrm{CH}_{2} \mathrm{CH}_{3}\right), 3.59(4 \mathrm{H}, \mathrm{t}$, $\left.J=6.7 \mathrm{~Hz}, \mathrm{O}-\underline{\mathrm{CH}}_{2} \mathrm{CH}_{2} \mathrm{CH}_{2} \mathrm{CH}_{3}\right), 5.82\left(4 \mathrm{H}, \mathrm{s}, \mathrm{N}-\mathrm{CH}_{2}-\mathrm{O}\right), 7.30(2 \mathrm{H}, \mathrm{m}), 7.43(2 \mathrm{H}, \mathrm{m}) ;{ }^{13} \mathrm{C}-\mathrm{NMR} \delta: 14.3$, 18.3, 30.9, 67.4, 72.4, 110.3, 123.6, 131.8, 171.1; IR $v_{\max }\left(\mathrm{cm}^{-1}\right)$ : $1099(\mathrm{C}=\mathrm{S}), 1288$ (C-O); EIMS, $70 \mathrm{eV}, m / z$ : $322\left(\mathrm{M}^{+}\right)$; Anal. Calcd. for $\mathrm{C}_{17} \mathrm{H}_{26} \mathrm{~N}_{2} \mathrm{O}_{2} \mathrm{~S}$ (322.46): C, 63.32; H, 8.13; N, 8.69; S, 9.94. Found: C, 63.24; H, 8.16; N, 8.67; S, 9.91.

1,3-bis(Cyano-1-methyl)-1,3-dihydro-2H-benzimidazole-2-thione (7e): Oily product; ${ }^{1} \mathrm{H}-\mathrm{NMR} \delta: 5.32$ $\left(4 \mathrm{H}, \mathrm{s}, \mathrm{N}-\mathrm{CH}_{2}-\mathrm{CN}\right), 7.56(2 \mathrm{H}, \mathrm{m}), 7.73(2 \mathrm{H}, \mathrm{m}) ;{ }^{13} \mathrm{C}-\mathrm{NMR} \delta: 31.9,111.9,118.3,119.4,134.7,179.4$; IR $v_{\max }\left(\mathrm{cm}^{-1}\right): 2,236(\mathrm{CN}) 1,102(\mathrm{C}=\mathrm{S}), 1,285$; EIMS, $70 \mathrm{eV}, \mathrm{m} / z: 228\left(\mathrm{M}^{+}\right)$; Anal. Calcd. for $\mathrm{C}_{11} \mathrm{H}_{8} \mathrm{~N}_{4} \mathrm{~S}$ (228.27): C, 57.88; H, 3.53; N, 24.54; S, 14.05. Found: C, 57.91; H, 3.56; N, 24.48; S, 13.91.

1,3-bis(1H-1,2,3-Benzotriazol-1-ylmethyl)-1,3-dihydro-2H-benzimidazole-2-thione (7f): Yellow Solid; m.p. $142-144{ }^{\circ} \mathrm{C} ;{ }^{1} \mathrm{H}-\mathrm{NMR} \delta$ : $7.07\left(4 \mathrm{H}, \mathrm{s}, \mathrm{N}-\mathrm{CH}_{2}-\mathrm{Bt}\right), 7.21$ (4H, m, benzimidazoline nucleus), 7.35 $(2 \mathrm{H}, \mathrm{t}, J=7.8 \mathrm{~Hz}$, benzotriazole nucleus), $7.52(2 \mathrm{H}, \mathrm{t}, J=7.8 \mathrm{~Hz}$, benzotriazole nucleus), 8.08 ( $2 \mathrm{H}, \mathrm{d}$, $J=7.8 \mathrm{~Hz}$, benzotriazole nucleus), $8.43\left(2 \mathrm{H}, \mathrm{d}, J=7.8 \mathrm{~Hz}\right.$, benzotriazole nucleus); ${ }^{13} \mathrm{C}-\mathrm{NMR} \delta: 55.3$, $110.1,111.7,119.9,124.0,124.6,128.5,130.2,132.6,146.2,169.6$. IR $v_{\max }\left(\mathrm{cm}^{-1}\right): 1108(\mathrm{C}=\mathrm{S}), 1,271$ $(\mathrm{C}=\mathrm{N})$; EIMS, $70 \mathrm{eV}, \mathrm{m} / \mathrm{z}: 412\left(\mathrm{M}^{+}\right)$; Anal. Calcd. for $\mathrm{C}_{21} \mathrm{H}_{16} \mathrm{~N}_{8} \mathrm{~S}$ (412.45): $\mathrm{C}, 61.15 ; \mathrm{H}, 3.91 ; \mathrm{N}$, 27.17; S, 7.77. Found: C, 61.23; H, 3.96; N, 27.26; S, 7.55.

\section{Conclusions}

In conclusion, the reported synthesis is reasonably efficient, direct, and operationally simple. We believe that the methodology presented herein can have wide applications for the development of synthetically useful benzimidazole-2-thiones that were previously inaccessible by other routes. 


\section{Acknowledgments}

We acknowledge the Dirección de Investigaciones Sede Bogotá (DIB) of Universidad Nacional de Colombia for financial support.

\section{References}

1. Hofmann, A.W. Noch einige Bemerkungen über Senföle. Ber. Dtsch. Chem. Ges. 1875, 8, $105-109$.

2. Wolf-Dieter, R. Reactions of carbon disulfide with Nnucleophiles. J. Sulfur Chem. 2007, 28, 295-339.

3. Johnson, T.B.; Edens, C.O. Complex Formations between iodine and $\mu$-mercapto-dihydroglyoxalines. J. Am. Chem. Soc. 1942, 64, 2706-2708.

4. Wang, M.-L.; Liu, B.-L. Reaction of carbon disulfide and $o$-phenylenediamine catalyzed by tertiary amine in a homogeneous solution. Ind. Eng. Chem. Res. 1995, 34, 3688-3695.

5. Wang, M.-L.; Liu, B.-L. Homogeneous catalyzed reaction of carbon disulfide and $o$-phenylenediamine by tetrabutylammonium hydroxide in the presence of potassium hydroxide. J. Chin. Inst. Chem. Eng. 2007, 38, 85-90.

6. Xue, G.; Huang, X.-Y.; Dong, J.; Zhang, J. The formation of an effective anti-corrosion film on copper surfaces from 2-mercaptobenzimidazole solution. J. Electroanal. Chem. Interfacial Electrochem. 1991, 310, 139-148.

7. Perrin, F.X.; Pagetti, J. Characterization and mechanism of direct film formation on a Cu electrode through electro-oxidation of 1-mercaptobenzimidazole. Corros. Sci. 1998, 40, 1647-1662.

8. Zhang, J.; Liu, W.; Xue, Q. Tribological study of a Mannich compound of 2-mercaptobenzimidazole in liquid paraffin. Tribol. Int. 1998, 31, 767-770.

9. Zhang, J.; Liu, W.; Xue, Q. The effect of molecular structure of heterocyclic compounds containing N, O and S on their tribological performance. Wear 1999, 231, 65-70.

10. Moreira, J.C.; Pavan, L.C.; Gushikem, Y. Adsorption of $\mathrm{Cu}(\mathrm{II}), \mathrm{Zn}(\mathrm{II}), \mathrm{Cd}(\mathrm{II}), \mathrm{Hg}(\mathrm{II})$ and $\mathrm{Pb}(\mathrm{II})$ from aqueous solutions on a 2-mercaptobenzimidazole-modified silica gel. Microchim. Acta 1990, 102, 107-115.

11. Dalal, D.S.; Pawar, N.S.; Mahulikar, P.P. Synthesis of 2-mercaptobenzothiazole and of 2-mercaptobenzimidazole derivatives using polymer-supported anions. Org. Prep. Proced. Int. 2005, 37, 539-545.

12. Bell, S.C.; Wei, P.H. Synthesis of heterocyclic fused thiazole acetic acids 2. J. Med. Chem. 1976, 19, 524-530.

13. Lin, S.; Lombardo, M.; Malkani, S.; Hale, J.J.; Mills, S.G.; Chapman, K.; Thompson, J.E.; Zhang, W.-X.; Wang, R.; Cubbon, R.M. Novel 1-(2-aminopyrazin-3-yl)methyl-2-thioureas as potent inhibitors of mitogen-activated protein kinase-activated protein kinase 2 (MK-2). Bioorg. Med. Chem. Lett. 2009, 19, 3238-3242.

14. De Almeida, M.V.; Cardoso, S.H.; De Assis, J.V.; De Souza, M.V.N. Synthesis of 2-mercaptobenzothiazole and 2-mercaptobenzimidazole derivatives condensed with carbohydrates as a potential antimicrobial agents. J. Sulfur Chem. 2007, 28, 17-22. 
15. Desai, K.G.; Desai, K.R. Green route for the heterocyclization of 2-mercaptobenzimidazole into $\beta$-lactum segment derivatives containing - $\mathrm{CONH}$-bridge with benzimidazole: Screening in vitro antimicrobial activity with various microorganisms. Bioorg. Med. Chem. 2006, 14, 8271-8279.

16. Proksa, B.; Turdiková, M.; Ertík, M.; Miroslav, K.; Preizingerová, T.; Fuska, J. Effects of derivatives of 2-mercaptobenzimidazole on polyketide biosynthesis in Penicillium frequentans. Biotechnol. Appl. Biochem. 1997, 25, 169-172.

17. Lobana, T.S.; Sharma, R.; Hundal, G.; Butcher, R.J. Synthesis of $1 \mathrm{D}\left\{\mathrm{Cu}_{6}\left(\mu_{3}-\mathrm{SC}_{3} \mathrm{H}_{6} \mathrm{~N}_{2}\right)_{4}(\mu-\right.$ $\left.\left.\mathrm{SC}_{3} \mathrm{H}_{6} \mathrm{~N}_{2}\right)_{2}(\mathrm{mu}-\mathrm{I})_{2} \mathrm{I}_{4}\right\} \mathrm{n}$ and $3 \mathrm{D}\left\{\mathrm{Cu}_{2}\left(\mu-\mathrm{SC}_{3} \mathrm{H}_{6} \mathrm{~N}_{2}\right)_{2}(\mu-\mathrm{SCN})_{2}\right\}_{n}$ polymers with 1,3-imidazolidine-2thione: Bond isomerism in polymers. Inorg. Chem. 2006, 45, 9402-9409.

18. Lobana, T.S.; Sharma, R.; Sharma, R.; Mehra, S.; Castineiras, A.; Turner, P. Versatility of heterocyclic thioamides in the construction of a trinuclear cluster $\left[\mathrm{Cu}_{3} \mathrm{I}_{3}(\mathrm{dppe})_{3}\left(\mathrm{SC}_{5} \mathrm{H}_{4} \mathrm{NH}\right)\right]$ and $\mathrm{Cu}(\mathrm{I})$ linear polymers $\left\{\mathrm{Cu}_{6}\left(\mathrm{SC}_{5} \mathrm{H}_{4} \mathrm{NH}\right)_{6} \mathrm{I}_{6}\right\}_{\mathrm{n}} \times 2 n \mathrm{CH}_{3} \mathrm{CN}$ and $\left\{\mathrm{Cu}(\mathrm{I})_{6}\left(\mathrm{SC}_{3} \mathrm{H}_{6} \mathrm{~N}_{2}\right)_{6} \mathrm{X}_{6}\right\}_{\mathrm{n}}(\mathrm{X}=\mathrm{Br}, \mathrm{I})$. Inorg. Chem. 2005, 44, 1914-1921.

19. Beheshti, A.; Clegg, W.; Dale, S.H.; Hyvadi, R. Synthesis, crystal structures, and spectroscopic characterization of the neutral monomeric tetrahedral $\left[\mathrm{M}(\mathrm{Diap})_{2}(\mathrm{OAc})_{2}\right] \mathrm{H}_{2} \mathrm{O}$ complexes $(\mathrm{M}=\mathrm{Zn}$, $\mathrm{Cd}$; Diap = 1,3-diazepane-2-thione; OAc = acetate) with $\mathrm{N}-\mathrm{H}^{\cdots} \mathrm{O}$ and $\mathrm{O}-\mathrm{H}^{\cdots} \mathrm{O}$ intra- and intermolecular hydrogen bonding interactions. Inorg. Chim. Acta 2007, 360, 2967-2972.

20. Rivera, A.; Maldonado, M.; Núñez, M.; Joseph-Nathan, P. Nucleophilic substitution at the aminalic carbon of some macrocyclic polyaminals. Heterocycl. Commun. 2004, 10, 77-80.

21. Rivera, A.; Maldonado, M. Unexpected behavior of 6H,13H-5:12,7:14-dimethanedibenzo $[d, i][1,3,6,8]$ tetraazecine (DMDBTA) toward phenols. Tetrahedron Lett. 2006, 47, 7467-7471.

22. Rivera, A.; Navarro, M.; Rios-Motta, J. Solvent-Free Synthesis of 2-(1H-benzimidazol-1-ylmethyl)-4-substituted-1-hydroxyaryl by the two component Mannich reaction between $6 \mathrm{H}, 13 \mathrm{H}$ 5:12,7:14-Dimethanedibenzo[ $d, i][1,3,6,8]$ tetraazecine (DMDBTA) and phenols. Heterocycles 2008, 75, 1651-1658.

23. Rivera, A.; Moyano, D.; Maldonado, M.; Ríos-Motta, J.; Reyes, A. FT-IR and DFT studies of the proton affinity of small aminal cages. Spectrochim. Acta A 2009, 74, 588-590.

24. Rivera, A.; Maldonado, M.; Ríos-Motta, J.; Navarro, M.; González-Salas, D. Novel access to 1-substituted-benzimidazoles via benzotriazole-mediated synthesis. Tetrahedron Lett. 2010, 51, 102-104.

25. Donia, R.A.; Shotton, J.A.; Bentz, L.O.; Smith, G.E.P., Jr. Reactions of mono- and di-amines with carbon disulphide. II. Methylenediamine and imidazolidine-carbon disulphide reactions. J. Org. Chem. 1949, 14, 952-961.

26. Mohamed, T.A.; Mustafa, A.M.; Zoghaib, W.M.; Afifi, M.S.; Farag, R.S.; Badr, Y. Infrared, Raman and temperature-dependent NMR spectra, vibrational assignments, normal coordinate analysis, and DFT calculations of benzoxazoline-2-thione. Vib. Spectrosc. 2010, 52, 128-136.

27. Lin, S.; Yang, L. A simple and efficient procedure for the synthesis of benzimidazoles using air as the oxidant. Tetrahedron Lett. 2005, 46, 4315-4319.

28. Ivanova, N.V.; Sviridov, S.I.; Stepanov, A.E.Parallel solution-phase synthesis of substituted 2-(1,2,4-triazol-3-yl)benzimidazoles. Tetrahedron Lett. 2006, 47, 8025-8027. 
29. Vojtech, M.; Petrušová, M.; Sláviková, E.; Bekešová, S.; Petruš, L. One-pot synthesis of 2-Cglycosylated benzimidazoles from the corresponding methanal dimethyl acetals. Carbohydr. Res. 2007, 342, 119-123.

30. Gallant, A.J.; Patrick, B.O.; MacLachlan, M.J. Mild and selective reduction of imines: Formation of an unsymmetrical macrocycle. J. Org. Chem. 2004, 69, 8739-8744.

31. Rivera, A.; Mejia-Camacho, A.; Ríos-Motta, J.; Dušek, M.; Fejfarová, K. 1,3-bis(ethoxymethyl)1H-benzimidazole-2(3H)-thione. Acta Cryst. 2010, E 66, o1135-o1136.

Sample Availability: Samples of the compounds $\mathbf{7 a}-\mathbf{f}$ are available from the authors.

(C) 2012 by the authors; licensee MDPI, Basel, Switzerland. This article is an open access article distributed under the terms and conditions of the Creative Commons Attribution license (http://creativecommons.org/licenses/by/3.0/). 